\title{
Alfred Verdross and Othmar Spann: German Romantic Nationalism, National Socialism and International Law
}

\author{
Anthony Carty*
}

\section{Introduction: The Context of the Verdross-Spann Association}

This article is a part of a section of the European Journal concerned with the international law thought of Alfred Verdross. It deals specifically with the inter-war period leading up to the German occupation of Austria and Verdross's temporary suspension from Vienna University in the years 1938-39. Given his relations with National Socialism, the difficult question arises whether some of his writings of this time ${ }^{l}$ represent firmly held views or whether they mark a bowing to difficult circumstances. Controversy surrounds this period of Verdross's life and work. It is readily admitted in circles close to him that he did accommodate to Nazi pressure. However, such sentiments are usually accompanied by the feeling and hope that a cloud will descend on this period and that the past will be decently forgotten. It is obvious from the October 1994 Austrian elections that nationalist traditions are not so easily made to vanish.

So it is thought worthwhile to explore some neglected parts of Verdross's interwar writings and his political activities leading up to 1938 . It will be argued that there is a continuity in one aspect of his work from 1918 to 1938 which requires that it be taken seriously as firmly held and clearly thought out opinion. Verdross adhered to a form of all-German nationalism which fits into a particular romantic idealist tradition. He was influenced at least in part by the work of Othmar Spann. In his relations with the Nazis he identified his position as nationalist. There is no doubt but that Verdross thought he could work with National Socialists but the evidence considered here ${ }^{2}$ does not indicate that he identified with it. In particular

* University of Derby.

I Especially the 1937 edition of Völkerrecht (Springer) Berlin.

2 The writer has had no access to private papers and, in keeping with the remit of the contribution to the European Journal, no account is taken of post-war (i.e. 1945) assessments of Verdross. 
the records available, mainly Nazi police archives, ${ }^{3}$ show that his scholarly work and academic and political activity were all closely scrutinized, leading to the firm conclusion that Verdross was not of their society, albeit he could hardly be accused of being in opposition to them. This article can merely hope to open up rather than to conclude debate as to whether German nationalism, and in particular the variety espoused by Verdross, has been irreparably compromised by the catastrophic and outrageous development and conclusion of the Third Reich.

Alfred Verdross was a German-Austrian intellectual and not simply a technical international lawyer during the 1920s and 1930s. As a diplomat of the GermanAustrian Republic in Berlin in 1919 he wrote a substantial argument for the immediate Anschluss of Austria to Germany, pleading, inter alia, that all German speakers, including those living in the Sudetenland and the South Tyrol, should be part of a single Germany. The overthrow of dynasties should also favour the freely expressed wishes of the German peoples to form one State. ${ }^{4}$ In the same spirit Verdross wrote a very critical contribution to a volume on the South Tyrol for the Vienna University Institute for Minority Peoples. ${ }^{5}$ Verdross pointed to a speech of US President Wilson that the Italian boundary should follow the lines of nationality, and felt that the language boundary between Italian and German was very clear. ${ }^{6} \mathrm{He}$ considered the rights of South Tyrol violated by the disregard of Wilson's undertaking. The Versailles Treaty was illegal (völkerrechtswidrig) in so far as it violated the Wilson Points. It was a question of when rather than whether it would be appropriate to ensure the means to restore the rights of South Tyrol. ${ }^{7}$

No attempt is made to consider Verdross's behaviour and the attitudes of others towards him after 1945. This would have to be the subject of another entire article.

4 Verdross, 'Deutsch-Österreich in GroB-Deutschland', in C. Haussmann (ed.), 7 Der Aufbau (with a foreword by L.M. Hartmann) (1919). What follows is a summary of the article. The concept of Austria-Hungary was used by the upholders of a Klein-Deutschland to suppress 40 million nonGermans in the Empire (at 15-16). The Groß-Deutschland solution for Austria simply meant that the Habsburgs and Hohenzollems could no longer divide the Germans in Austria who could then vote for the großdeutsche solution (at 19). This represented a putting into practice, in the case of the Germans, of the principle of the French Revolution that every nation had the right of selfdetermination to form a State of its own, without having the right to dominate any other State (at 31-32). The right of self-determination that each nation must build its own State means: '... Staat und Nation gehören untrennbar zusammen, da die Nation die natürliche Verbindung der Menschen bildet. Sie ist zusammengeschmiedet durch das Gefühl der Zusammengehörigkeit; die Einheit der Nation beruht daher nicht auf Gewalt und Eroberung, wie es bei den historisch gewordenen Staaten der Fall ist, sondern auf dem Recht der Selbstbestimmung...' (at 32).

5 'Deutschsüdtirol', Drei Vorträge von Voltelini, Verdross, Winkler, in W. Winkler (ed.), Schriften des Institutes für Statistik der Minderheitsvölker an der Universität Wien, Vol. 5 (1926).

6 Ibid., at 5. After a complex discussion as to whether Austria could benefit from an Allied commitment to Germany to conclude peace on the basis of Wilson's 14 Points (at 6-7), Verdross notes that the Allies decided to implement a commitment to Italy, on the basis of which it entered the war, to give it the Brenner Pass border with Austria (at 7-8). Verdross then considers Italian government undertakings to respect German minority rights in South Tyrol and, in his view, the systematic violation of these rights, especially after Mussolini came to power (at 9 et seq.).

7 Ibid., at 24-26. Nothing was to be expected of the mechanisms afforded by the League of Nations. Verdross speaks of 'saving' South Tyrol. His paper appears mainly concerned with guaranteeing basic minority group rights, at 25 . 
In the 1930s Verdross's All-German (gesamtdeutsch) nationalism came with a sympathy for National Socialists, particularly students, in the years 1934-38. This subject has been considered by Oliver Rathkolb in his study of the Vienna Law Faculty, ${ }^{8}$ which has received no written response from the Faculty since its publication. In the course of investigations of Verdross conducted by Nazi authorities during the period of his suspension after March 1938, he himself presented a statement for the attention of the Reichskommissar for the Reunification of Austria with Germany. It is entitled: 'The National-political and National-legal (nationalrechtliche) Activities of Univ. Prof. Dr. A. Verdross'. The statement lists his collaboration with NS circles in his desire to favour All-German (gesamtdeutsche) views. He cites among his publications the 1919 piece already discussed and numerous other short pieces on the question of Anschluss, the Sudeten Germans and minority rights. Verdross himself stressed his support of National Socialist students, all of which served, in his view, to demonstrate his nationalist stance. ${ }^{9}$

All of this suggests that Verdross's association with National Socialism was not a short-lived, purely opportunistic or otherwise 'weak' bowing or bending to circumstances. The apparently cursory approval of National Socialism in the 1937 textbook, Völkerrecht ${ }^{10}$ is rooted in a deep commitment to German nationalism. When he was reinstated to teach again in the spring of 1939 he undertook regularly the general introduction to the study of law under the title Volk und Staat. ${ }^{11}$ In the textbook (Völkerrecht (1937)), under the rubric Volk und Staat (Völkerrechtliche Grundbegriffe) he presented a firmly nationalist perspective which is a consistent development of the ideas in the 1919 article. There are three elements in his doctrine. The individual man exists only as a member of a people; 12 the goal of a peaceful international order is to ensure that each people is able to build its own

8 Rathkolb, 'Die Rechts- und Staatswissenschaftliche Fakultăt der Universität Wien zwischen Antisemitismus, Deutschnationalismus und Nationalsozialismus 1938, davor und danach', in G. Heiss et al., Willfahrige Wissenschaft (1989) 197 esp. 217-219.

9 Gauakt No. 259658, Österreichisches Staatsarchiv, Bericht uber Alfred von Verdross.

10 A. Verdross, Völkerrecht, supra note 1, at 29. In his statement to the Reichskommissar (Gauakt, supra note 9) Verdross cites several critical reviews of this work. In Völkerbund und Völkerrecht a leading NS international lawyer, G.A. Walz, praises the work as '... eine völkerrechtswissenschaftliche Gesamtschau vom deutschen Standpunkt...' (emphasized by Verdross). The Berlin Journal Kulturwehr (1938) at 60 states that the book is already the most widely recommended in German universities. Verdross underlines the review's favourable remarks about his objective treatment of nationality as a concept, avoiding the liberal subjectivism of French approaches to the topic. Once again Verdross emphasizes the characterization of the book as 'das bedeutendste deutsche Lehrbuch des Völkerrechts...' Consistently Verdross stresses his commitment to German nationalism and does not try to present himself as a National Socialist.

11 See the official Vienna University Vorlesungsverzeichnis from the Wintersemester 1939-40 until the Wintersemester 1944-45.

12 Völkerrecht, supra note 1, at 39: '... Wir haben schon früher darauf hingewiesen, daB es keine Menschen an sich, sondern nur Menschen bestimmter Art gibt. Die höchste natïliche menschliche Art bildet das Volkstum; daher gehört jeder Mensch einem bestimmten Volkstum an...' 
State; ${ }^{13}$ and it is the State and the international legal order's function to serve the well-being of peoples, and not vice versa. ${ }^{14}$ This is the background against which Verdross would have undertaken in the 3rd Trimester of 1940 a course entitled Der Neuaufbau Europas im Lichte des Völkerrechts (The Rebuilding of Europe in the Perspective of International Law). ${ }^{15}$

In other words, during the whole period of the 1920s and 30s Verdross's intellectual stance and convictions were clear and did not change. How he chose to present himself after 1945 is another matter and is not the subject of this article. Instead the concern is, without the benefit of hindsight, to investigate what exactly he himself understood by nationalism and how he understood it to be compatible with some version of National Socialism. In the space at present allocated, and in the absence of access to priyate papers, a beginning will be made by exploring the intellectual affinities between Verdross and Othmar Spann. Spann was a colleague in the Vienna Law Faculty who has a reputation as a leading nationalist theorist of the inter-war period, interested in collaboration with National Socialism, but removed in 1938 by the Nazis, never to be reinstated. Given the very extensive research on Spann's close, but eventually very troubled relations with the Nazis, it is particularly interesting to explore the intellectual relationship between the two against a background of scholarship where the ambiguities of Spann's position have been extensively highlighted. This experience can only help in assessing possible ambiguities in Verdross's position. ${ }^{16}$

That is to say it will not be attempted in this short article to give a systematic account of the entire content of Verdross's 1937 textbook. This was undertaken in 1939 by Ernst Engelberg in an article published in France. ${ }^{17}$ This very critical piece highlights Verdross's engagement for an international law of peoples (un droit des peuples) and stresses that Verdross attached to this framework the pre-1914 doctrine of the droits fondamentaux of States, thereby radically subjectivizing international law and destabilizing it by relying on a doctrine of absolute State sovereignty. ${ }^{18}$ Engelberg's critique cites the work of Bristler ${ }^{19}$ but it puts forward the speculative argument that the reason Verdross combines these two sets of ideas is to give free rein to an arbitrary and expansive NS foreign policy. ${ }^{20}$ The object of the present article is not to refute this general argument but to begin scholarly analysis of

Mid., at 40 , citing Augustine stating that God chose to allow the variety of peoples and languages to persist and '... daB es für den Frieden der Welt am besten bestellt wäre, wenn jede 'gens' ihren eigenen Staat bilden würde...'

14 Ibid, at 41: '... ist die Idee des Staates auf das Volk rückbezogen; da es seine Aufgabe ist, das Volk zu schützen und zu vervollkommen... Da aber die Staaten nur äußere Organisationen lebendiger Völker sind, steht auch das Völkerrecht letztlich im Dienste dieser...' See the Vorlesungsverzeichnis of Vienna University for 1940.

16 See A. Mohler, Die Konservative Revolution in Deutschland 1918-1932. Ein Handbuch (4th ed., 1994) 413, and Ergänzungsband, 58.

17 'Les bases idéologiques de la nouvelle conception de droit international de M. Alfred von Verdross', 46 RGDIP (1939) 37-52.

18 Ibid., at 39 and 44.

19 Die Völkerrechtslehre des Nationalsozialismus (1938) at 42 of Engelberg's text.

20 Ibid. 
Verdross's work during this period by examining as closely as possible the metaphysical foundation he gives to an international law of peoples.

\section{The Concept of Relationship in Spann's Social Theory}

Spann developed an integrationalist and/or organic theory of the relationship of the individual to community, of which his theory of law, State and society was part. Some introduction to these basic ideas is necessary, if only to give some general orientation as to how Verdross could see them as applicable to international law. Later, some of the 'ambiguities' in Spann's thought can be returned to. The two words (integrationalist, organic) refer to the idea that all relationships should be in some sense essential, necessary, thereby implying a mutual boundedness, making separation incompatible with continued independent existence. Spann was far from denying that the Volk (people) is also bound within a community of Menschheit (mankind). Rather it is the nature of this relationship which needs to be explored. He sees it as transforming so utterly individual identity that it makes no sense to think of individuals outside relationship. A favourite expression of Spann was 'Selbstsein durch Sein im anderen'. ${ }^{21}$ This is within a romantic tradition in the sense that great importance is attached to the personal, emotion, feeling, etc. Thus, Spann's view of relationship is of a direct (unmittelbar) meeting of hearts in which separate identity is transformed rather than lost. ${ }^{22}$

On the first page of the introduction to Die Einheit des rechtlichen Weltbildes ${ }^{23}$ Verdross remarks that after completion of his manuscript (1923) the second edition of Othmar Spann's Gesellschaftslehre (also 1923) came to his attention. This he regards as the first serious attempt to present State and law as different parts of society as a whole. Spann is accredited with denying the dominant doctrine that law is created by the State, in favour of the phenomenological approach that the State should be seen as a unity of action while the law is a unity of values. He mentions Spann again later in the same text in quite general terms but, nonetheless, in terms which are central to Verdross. The 16th century Spanish school of international law, for instance Vitoria, recognized the State as integrally and necessarily part of an international order, while the modern school of positivism sees the State as free to choose whether to bind itself 'externally' and 'accidentally' to international law. The relationship is not essential (wesensnotwendig), so that the State can leave it at will. In contrast, the old doctrine is that States and international law stand, in their

21 O. Spann, Gesamtausgabe Vol. 4, Gesellschafislehre (Social Theory), (W. Heinrich and others (ed.), 1969, reproducing the 3rd edition of 1930) 144: '... der menschliche Geist hat nicht Einzelheit sondern Gezweiung ... ohne Sein im Andern kann der menschliche Geist ebensowenig ein Selbst sein ... wie man ohne Wind segeln kann...'

Ibid., at 147: '... Der andere Geist, das Du, das uns gegenübertritt, das ist unser Herz, unser anderer Selbst...'

23 A. Verdross, Die Einheit des rechtlichen Weltbildes auf Grundlage der Völkerrechtsverfassung (The Unity of the Legal World...) (1923) at 1-2. 
relation to each other, in an original mutual boundedness as of the Whole to the Parts. ${ }^{24}$ At this point Spann is introduced as having been taken to assert that the universalist perspective is the only correct social theory and he cites Spann on the place of the Volkstum as a member (Glied) of mankind (Menschheit). ${ }^{25}$

\section{Verdross's Comments on Spann's Social Theory}

After the publication of the Einheit Verdross wrote an extensive theoretical article in which he gives central place to Spann. ${ }^{26}$ The argument of the article appears again in Die Verfassung der Völkerrechtsgemeinschaft. ${ }^{27}$ Once again Verdross is concerned with the nature of relationship, firstly at the individual-social level and subsequently with the implications for international order. Kelsen and Spann are set together as recognising that a meaningful unity ${ }^{28}$ can only be won from the perspective of an objective order. The latter cannot arise out of the coming together of independent units. These independent units must, somehow, already be members of a meaningful order. ${ }^{29}$

The notion of objective value as meaningful, is opposed to subjectivist, i.e. individualist, explanations of meaning in a way which clearly anticipates the individual-collective assumption underlying Verdross's textbook concept of Volk in 1937. International law theory is being drawn from a primary social theory. Verdross has, as seen above, claimed to develop an objective concept of the Volk in which the individual is integrated, while the Volk itself is mid-way in an ascending series of identification-producing relations. The key concept of universal also appears in opposition to that of individual. These elements are taken from Spann in the synthesis which Verdross makes of his thought in the Gesellschaftslehre. So it is not the separate individual who is the starting-point but the universal totality/whole of society (das universale Ganze der Gesellschafi). The individual can only be understood as an offshoot of the totality (die Ausgliederung von Ganzheiten). A decisive conclusion follows. The human being as such does not exist. For he is always a member of a particular family, class, State, cultural world, and finally of

24 A. Verdross, Die Einheit..., supra note 23, at 41: 'für welche Völkerrecht und Staaten in ursprünglicher Aufeinanderbezogenheit stehen, wie das Ganze zu seinen Teilen, indem die Staaten die Glieder dieser Einheit darstellen...'

25 Ibid.

26 Archiv für Rechts- und Wirtschaftsphilosophie, Die gesellschafiswissenschaftlichen Grundlagen der Völkerrechtstheorie, Vol. XVIII (1924/25) 413-431, reproduced in H. Klecatsky et al. (ed.), Die Wiener rechtstheoretische Schule, Vol. II (1968) 2079.

27 [The Constitution of the Intemational Law Community] (Springer Verlag, Wien-Berlin, 1926).

28 Einheit is a key word for Verdross.

29 Ibid., at 2080: ‘... denn nicht mehr darum kann es sich nun handeln, wie aus dem Aufeinanderwirken von ursprünglich selbständigen Einzeinen eine soziale Einheit entsteht, sondern die Einzelnen werden in Wahrheit von vornherein als die Organe, als die Glieder einer sinnvollen Ordnung betrachtet, da erst von diesen aus ihr Handeln gedeutet werden kann...' 
the Cosmos, but a human being never exists who was somehow never a member of anything. ${ }^{30}$

In particular universalism expresses conceptually the centrality of relationship in opposition to individualism. ${ }^{31}$

Verdross uses the universalist method to oppose a number of individualist approaches to international law. Universalism will resist the ethno-centricity of the Roman approach to treaty obligation which supposed that a community could only bind itself in terms of its own values, as it was not integrated within a wider world community. ${ }^{32}$ Yet it has to be seen that Verdross is, at the same time, aligning himself with the conservative German Sonderweg against the English and French Enlightenment. He connects his rejection of the idea that States can simply bind themselves to one another through treaties with the idea that individuals can found States through the instrument of a social contract, in fact the very basis of English and French democratic liberalism. ${ }^{33}$ This very strong anti-individualist rhetoric is the background to the assumption that it is not the treaty itself but the underlying principle pacta sunt servanda which expresses the objective order which is prior to the individual. ${ }^{34}$ The alternative is nothing but '... subjektivistisches Naturrecht... 35

The decisive conclusion to Verdross's argument is that he speaks not of international law or legal order but of the constitution of the international law community. Organic theory is central to the shaping of a particularly close association of States in a single and distinctive community. Biological and cultural metaphors abound, although they are more fully developed in the 1926 book. Two States cannot deal directly with one another as two foreign beings (fremde Wesen) but only through the incorporation of one under the other, so that it becomes a member (Glied) of it, or both are subordinated (unterworfen/als Glieder einer ihnen übergeordneten Ganzheit). ${ }^{36}$ A dichotomy is drawn between hegemonial relations and relations of union (Einheit/Universalität). The autonomous nation-State has no place in Verdross's thinking. He is drawing on Spann for a theory of international community. Autonomy on its own contains within itself a drive to hegemonial

Ibid., at 2080: '... Einen Menschen an sich gibt es also nicht. Denn er ist Glied einer bestimmten Familie, Glied eines bestimmten Standes, Glied eines bestimmten Kulturkreises, Glied der Menschheit, endlich Glied des Kosmos, niemals aber Mensch, der nicht irgendwie Glied wäre...'

Ibid., at 2081. Causality, individualism and empiricism are lumped together '... während ihr Widerpart, die universalistische Gesellschaftslehre, ihr innerlich nicht nur nicht entgegensteht, sondern geradezu ihre Grundlage bilden will, da sie es sich ja zur Aufgabe gesetzt hat, das Gesamtganze aller Teilganzen der Gesellschaft, darunter auch das Teilganze Recht, unter derselben Einstellung, wie die Rechtstheorie, nämlich als Ordnung von Normen grundsätzlich zu erfassen...' Ibid., at 2082-3.

33 Ibid., at 2085. The doctrine of auto-limitation coming from Bergbohm and Jellinek '... ist der getreue Abklatsch der zweiten Spielart des zwischenmenschlichen Individualismus, der den Staat durch Vertrag zwischen den bisher unverbundenen Menschen entstehen läßt...'

36 Ibid., at 2090. In the Verfassung Verdross cites this article's argument virtually word for word, at 38, also 7-8: 
incorporation which can only be satisfied through world domination through a single State. In an individualist perspective one State is drawn into the system of another. ${ }^{37}$ The notion of a stable external public law (äußeres Staatsrecht) is unrealistic because even this supposes that outside the State another State is present. ${ }^{38}$

Drawing from Spann's Kategorienlehre (1924), ${ }^{39}$ Verdross's concept of community has definite implications for acceptance into the community through recognition. Thus, to recognize another State in a particular field means nothing other than to regard it as a member of the same community. This is the meaning of the primacy of the community of States. ${ }^{40}$ However, there is no explicitly exclusivist concept of community intended here. Verdross highlights Spann's acceptance, again drawing on the Gesellschaftslehre that the Volkstum is not the final totality, but itself part of a higher totality, which is humankind. ${ }^{41}$ At the same time, Verdross does not understand by humankind (Menschheit) a world State of atomised individuals. ${ }^{42}$ There is a community of States. The individual State and the community of States do not stand in opposition to each other as two foreign bodies (Fremdkörper) whose wills clash in a power struggle. Verdross sees himself as presenting a serious social theory of international relations, opposing, for instance, a power politics theory. Hence it is important to assert the organic nature of the relation of State to State community. The State community lives only in and through its members, the States. ${ }^{43}$

At the same time, one might regard Verdross's theory as a type of 'metaphysical decoration' for his equally held and more conventional view that international law does not exist apart from States, that it has no organs of its own, that international organs such as the League of Nations or the World Court are called into being by States. ${ }^{44}$ Only States are the direct organs of international law. An international law independent from State law (Staatsrecht) is impossible. However, Verdross regards his organic theory as essential to overcome the idea that international law is therefore unilaterally dependent on State law. Unity (Einheit) means 'members one of the other'. 45

37 Ibid., at 2090: '... dadurch wird aber der andere Teil zum Gliede dieses herabgedrückt...'

38 Ibid., '… während der zum Gliede gewordene ehemals fremde Staat sich nicht mehr außerhalb sondern innerhalb des einzigen Staates befindet...'

39 O. Spann, Gesamtausgabe, Vol. 6, Kategorienlehre, supra note 21 and infra note 80.

40 Ibid., at 2092: '... Einen anderen Staat in einem bestimmten Bereich anerkennen, heißt so nichts anderes, als sich mit ihm als Glieder derselben Gemeinschaft betrachten...'

41 Ibid., at 2093-4: '... das Volkstum keine letzte Ganzheit bildet, sondern selbst wiederum als Glied höherer Ganzheiten, letztlich der Menschheit erscheint...'

42 See above in his submission to the NS authorities his defence of his textbook as representing objective rather than subjective nationalism, in the Gauakt (supra note 9).

43 Ibid., at 2094: '... vielmehr lebt die Staatengemeinschaft nur in ihren Gliedern, den Staaten...'

44 Ibid., at 2094-5. 


\section{Spann and 'Die Verfassung der Völkerrechtsgemeinschaft' 46}

In the Verfassung Verdross repeats these arguments, referring to and quoting from Spann. Here it is intended not just to follow up these sources, but to highlight some distinctive features. Verdross distinguishes himself from Kelsen in insisting that the State cannot be dissolved (sich nicht auflösen) into the legal order. Legal Order and Legal Community are inseparable but not reducible one to the other. For this proposition Verdross relies directly on Spann. A positive order of legal norms is valid only in relation to the actual conduct of a particular community. The idea of the particularity of law in relation to concrete communities is implied. 47 The concept of Legal Community is developed in line with Spann's notion of relationship and totality. Verdross adds a notion of the boundedness of every individual man (Mensch) to God. Men are related to one another through a common ground (Urgrund) so that they are not related to one another directly as separate individuals but through a higher unity. ${ }^{48}$

The strength of the organic approach is that it does allow unity in difference without the one entity having to be dissolved into the other. The autonomous collective community is not a threat to international society precisely because it is intimately integrated into it. Unity (Einheit) means not removal of but the relativizing of difference (Vielheit in Einheit). ${ }^{49} \mathrm{It}$ is worth stressing, however, that relationship still has a homogeneous tendency, existing between those who are related to the same community rather than foreign to one another. 50

Nonetheless, in the legal context the concept of relatedness has a special meaning and with respect to this, Verdross treats Kelsen and Spann as on the same track, although Spann's doctrine of Ebenbildlichkeit is regarded as deeper than Kelsen's pure theory of law. Foreignness and similarity have to do with the purity of categories of thought, the distinguishing of intellectual disciplines. Some of Verdross's (and Spann's) language which seems to come very close to the racial expressions of National Socialism is in fact primarily concerned with avoiding category mistakes in thought. Law is part of a legal totality, while politics, economics, etc. are part of their own 'totalities'. 51

Ibid., at 2095: ' ... Völkerrechtsverfassung und Staatsverfassung verhalten sich daher zueinander so, wie der Makrokosmos zum Mikrokosmos, wie das Ganze zu seinen Gliedern...'

46 A. Verdross, Verfassung, supra note 27.

47 Verfassung, supra note 27, at 6-7. Verdross wishes to oppose this time-space structured notion of law and community to Kelsen's apparently purely hypothetical, logical concept of law: see especially at 22-23 later.

48 Ibid., at 7.

49 Ibid., at 38.

50 Ibid., at 8: '... Eine Beziehung ist also nicht zwischen fremden sondern nur zwischen verwandten d.h. solchen Gemeinschaften möglich, die sich als Ausgliederungen desselben umfassenden Zusammenhanges darstellt...'

51 Die gesellschaftswissenschaftlichen Grundlagen der Völkerrechtstheorie, supra note 26, at 2092: ‘.. Das Ganze wird in den Teilen nach der Weise seiner selbst geboren, was besagt, daB keine Ganzheit ihrem Wesen nach Fremdes in sich enthalten kann. Alle ihre Glieder müssen ihres 
In the Verfassung this leads Verdross to draw a very sharp distinction between his Spann-based theory of law and that of the Spanish school with which he is otherwise deeply sympathetic, as was seen in the first mention of Spann in the Einheit (above). ${ }^{52}$ Now Verdross insists against Suarez that international law cannot be derived logically from moral (sittliche) norms but has to come about through the experience of a consensus gentium. ${ }^{53}$ While natural law is necessary as a foundation of international law, legal positivism is correct to insist upon methodological purity, and law can only be effectively derived from higher legal norms. ${ }^{54}$ So the organic theory of Spann is employed to support the mutual interaction of State and international community as equal expressions of a unified legal world. ${ }^{55}$

Verdross identifies the political or ideological concerns of the Spanish school as the same (i.e. as also concerned with achieving a unified legal world). So Vitoria compares the individual State as pars totius orbis. It is not States but the State community which is the logical first, the Totality which then divides itself up into parts (as States). ${ }^{56}$ Positive international law in the sense of law derived from State will is clearly not enough to ground an international legal order. The principle pacta sunt servanda has a different status as the form in which the relative independence of States expresses itself in the organic whole of the universal international legal community. Organic metaphors abound in the description of this principle. ${ }^{57}$ At the same time, the concept of universalism taken from Spann expresses the nature of the relationship of the State to the international legal community not within a framework of inter-national law but überstaatliches and übernationales law. Universalism places the central stress on relationship, which marks the integral association of the part to the Totality, which in turn divides itself into parts. Here Verdross reiterates the argument he had developed from Spann in his article; between the Völker as individuals exists literally nothing, but over them - in the sense of encompassing them - there is humanity (Menschheit) of which they are a part and an expression. ${ }^{58}$

Verdross only partially carries over his theoretical discussions into his examination of practical technical questions of international law. For instance,

Stammes, ihrer Art sein. Daher ist das Recht durch und durch rechtlich. Es besteht nur aus rechtlichen Unterganzen... Jedes rechtliche Unterganze ... hat die Natur des ganzen Rechtes an sich... Die Glieder müssen selbst das Ganze im Kleinen sein, Fleische vom Fleische des Ganzen...' (italics in original).

52 See supra Part II.

53 Verfassung, supra note 27, at 26.

54 Ibid., at 28-29.

55 Ibid., again, at 38-39.

56 Ibid., at 39.

57 Ibid., at 40: '... Die Staatengemeinschaft selbst aber wird nicht erst durch das positive Völkerrecht, sondern durch die Norm pacta sunt servanda begründet. Sie bildet die Keimzelle der Staatengesellschaft, die Urquelle des Völkerrechts. Schon sie stiftet eine, wenngleich nur der Anlage nach wurzelhafte Verknüpfung zwischen den Staaten, die nur der aktuellen Ausgestaltung durch zwischenstaatliche Vereinbarungen hart...'

58 Ibid., at 40-41, a virtually word for word repetition of the argument of the article on the organic relationship of State to international legal community. 
Verdross demonstrates his continued hostility to the social contract theory of the State and connects this hostility with his unwillingness to accept that States can simply bind themselves through treaties. International law cannot, therefore rest upon a foundation of State consent alone. Bindingness is impossible without the higher principle pacta sunt servanda. ${ }^{59}$ When Verdross comes to examine the question whether there are international law rules on the origin of States and the significance of the institution of recognition he gives a long account of State practice on provinces breaking away from the 'mother' country. He concludes that customary law takes over the idea that State organs are accepted by international law when they are able to assert themselves internally and externally on territory. ${ }^{60}$ However, on recognition itself Verdross reasserts that a treaty cannot of itself create duties of international law among States. The basic norm pacta sunt servanda makes a treaty legally possible and the recognition-treaty then realizes it. ${ }^{61}$ The problem of how recognition is possible as a mutual act unless each side is already an effective legal actor is overcome by a notion of potentiality, completed in community. ${ }^{62}$ This approach could have been more fully developed in terms of mutual recognition as part of a process of incorporation in community, but Verdross does not undertake this. Theory in his work largely comments on other theory rather than work itself out in the details of international law. This is not, however, to downplay the importance of theory in Verdross's vision of political society and international relations.

\section{The Political Background to Verdross's Theory of International Law}

What has been offered purports to be an exhaustive account of Verdross's use of the thought of Othmar Spann. No speculation will be proffered as to why there is no use made of Spann's thought in the lectures he gave one year later, entitled Le fondement du droit international. ${ }^{63}$ Nor will it be asked why in his post-war autobiographical contribution ${ }^{64}$ Verdross makes no mention of his article on Spann as providing a supporting background to the Verfassung. Indeed no guess will be made as to why Verdross does not cite Spann in his 1937 Völkerrecht at all. In the present context uncertainty about Verdross's thought will be focused on the relationship between his political Christianity and what is called here his romantic nationalism. It is this combination which appears to have led to his suspension in 1938. They give a foundation for the claim that Verdross was not simply a technical

64 'Alfred Verdross', in N. Grass (ed.), Österreichische Rechts- und Staatswissenschaften der Gegenwart in Selbstdarstellungen (Innsbruck 1952) 201 at 205. 
international lawyer reproducing legal knowledge for students but also an engaged intellectual concerned to shape German-Austrian political relations within a community of European and Christian nations, as he understood these concepts. The meaning or significance of Verdross's teaching and research in the university can be best understood when they are seen in the light of his wider political activity. Indeed it is this wider dimension of Verdross's life which led to his suspension from Vienna University by the Nazis in 1938.

The most rapid introduction to Verdross's political engagement can be had by considering a letter which he wrote to the Austrian Chancellor Schuschnigg on 6 March 1938 in which he called for an understanding between Christian political elements and moderate National Socialists in Austria in order to avoid the complete take-over of National Socialism by anti-Christian elements, such as was now the case in Germany. The collectivist or corporativist and nationalist style of thinking of Verdross seems unmistakable in the following passage of the letter. It assumes that such collaboration in Austria might be possible:

...Würde es hingegen gelingen, in den volkspolitischen Referaten eine Zusammenarbeit zwischen den gesamtdeutsch eingestellten christlichen Gruppen und den gemäßigten Nationalsozialisten herbeizuführen, dann besteht die Hoffnung, daB die christliche Führung in Österreich dauernd gesichert bleibt. Auch dieser Weg ist gewiB nicht ohne Gefahren, aber er scheint mir der einzige zu sein, der imstande ist, das Programm der Maiverfassung: die Verschmelzung aller guten Österreicher zu einem christlich-deutschen Volk zu verwirklichen. Gleichzeitig aber würde ein solcher Erfolg die christlichen Elemente im Deutschen Reich stärken und auch dort eine Versöhnung zwischen Christentum und Nationalsozialismus vorbereiten helfen...65

It is the relationship between Christian political nationalism and National Socialism in Verdross's thought and conduct which immensely intrigued the NS authorities and left them sceptical about him but willing to accept him. In fact opinion was very divided. One view from the Reichsführer SS Office was that Verdross was a liberal democrat and a Christian but willing to adapt to the new political circumstances. ${ }^{66}$ Another view, held by the leader of the NS Dozentenbund in Vienna University was that Verdross had firmly corporativist Christian-German political views which he

65 Gauakr, supra note 9 translated by the author as follows: 'Were it, on the other hand, possible, to bring about cooperation between the All-German (gesamtdeutsch) oriented Christian groups and moderate National Socialists, then there would be hope that the Christian leadership remained thereby assured in Austria. This approach is not without certain dangers, but it seems to me to be the only way to achieve the programme of the May Constitution: the melting of all good Austrians into a Christian German people. Such a success might strengthen Christian elements in Germany itself where anti-Christian elements dominate within National Socialism.

66 See, for instance, in Gauakt No. 259658, supra note 9, the Report of SS Obersturmführer Mullner, 24 August 1942 SD des Reichsfuhrers SS Wien (III A 3 PA 527/38) which remarks '... ohne jedoch eine feste bestimmte Grundhaltung einzunehmen, offenbaren seine zahireichen auch international anerkannten Schriften und Werke neben einer liberalen demokratischen Denkart (Verdross war ein Schüler des nunmehr von ihm bekämpften jüdischen Universitätsprofessors Kelsen) eine starke christiich-philosophische Bindung... In charakterlicher Hinsicht ist er weich. unentschiossen und wandelbar. Er versucht nunmehr den politischen Verhältnissen gerecht zu werden und sich ihnen anzupassen...' 
wished to use to shape National Socialism in a particular direction. This he had failed to do, but he had to be watched carefully as his accommodation to existing political realities was purely pragmatic. 67

In this context it is believed that a brief exploration of Spann's own views, his difficulties with National Socialism and critical reflection on these will help to throw some light on Verdross's own position and perhaps even draw out some concealed assumptions implicit in his international law theory. In particular, it is intended to focus on the romantic aspect of Spann's thought and on his 'spiritual' (geistige) nationalism. Given the understanding of these concepts which will be offered here, it is clear that Verdross and Spann represent permanent features of German political/legal culture which are very much alive in the Germany of today.

Nationalism as opposed to cosmopolitanism means that humanity expresses itself through nations. A multiplicity in unity means that humanity divides itself up into nations, which come together with one another in humanity. While Spann firmly places humanity before the individual Volk (people) he does so only in the sense that the Volk does not enjoy an independent existence, and not in the sense that in whatever possible scale of vaiues humanity is more important than the nation. Indeed there is firm opposition to the alternative German tradition of the world citizen and a deep disdain for the person who claims not to be attached to any particular country. ${ }^{68}$ At the same time the community of Völker is expressed in the notion of the Christian, Western culture of Europe into which individual States are compelled through treaties and other means to find their place as parts of a greater whole. ${ }^{69}$ The notion of individuality has to be bound to relationship and not based on autonomy.

Spann's theory has implications for the origin of States which, as already noted, Verdross only partially adopts. The human spirit exists not in individual isolation but in an unfolding mutuality (Gezweiung). The dimension of dialogue is central to romantic nationalism. It is speech - being spoken to by the other - which awakens the self. Meaning is found in exchange, in a mutual self-giving, where, of course, individuality is enhanced rather than extinguished. ${ }^{70}$ Within a context in which the

Dozentenführer der Universität Gauleitung Wien (Dr. A. Marchet) 19 September 1942 Gauakt, supra note 9: '... Er gehört jener katholisch-nationalen Zwischenschicht an, die für uns unerwïnscht ist...' Marchet attributes Verdross's suspension in 1938 to his above cited letter, which he interprets simply as an attempt to split the NSDAP so that a Christian leadership could be maintained in Austria and strengthened in Germany. Verdross was rehabilitated because he was able to persuade the authorities that his real intention was merely to help ward off the threat of civil war in Austria. With Verdross rehabilitated, Marchet concludes that his present conduct is a calculated conformism: '... DaB er nach dem Umbruch vorsichtig alles vermeidet, was ihn in Schwierigkeiten bringen konnte, daB er auch z.B. bei Sitzungen bemüht ist, einen nationalsozialistischen Standpunkt zu vertreten, ist selbstverständlich. Ebenso bin ich aber völlig überzeugh daB er kein unbedingter und verläßlicher Nationalsozialist ist und sein kann'. O. Spann, Gesellschaftslehre, supra note 21, at 568-570; see again Verdross, Völkerrecht, supra note 1, at 39: '... Ein Mensch kann allerdings sein ursprüngliches Volkstum verlieren, aber nur dadurch, daB er sich in ein anderes, verwandtes Volkstum eingliedert...' Ibid., at 614.

Ibid., at 144149. 
primary models of human relationship are family and friendship ${ }^{71}$ Spann opposes the founding of States in terms of an original contract in favour of the idea of a reshaping of group relations, which have always to be seen as evolving, regrouping, taking on an ever-changing variety of forms. ${ }^{72} \mathrm{~A}$ romantic concept of immediate personal relations is thus treated as equally applicable to group relations even at an international (correctly, universal) level.

However, Spann's understanding of the detail of the organization of a State is authoritarian in the sense, opposed to democratic liberalism, that there are considered to be objective values constituting society's meaning-structures and that there are individuals and groups who arise within the society as best suited to develop and apply these values. In such a context, law does not have the task of guaranteeing the private freedom of the individual. Rather, a good law is one which reflects the fruitful and successful exchange of individuals in community. ${ }^{73}$ Popular sovereignty in the French sense, with its accompanying idea of uniform, individual equality is opposed by a concept of organic (here 'Stand') community in which each individual has an 'appropriate' place. ${ }^{74}$ Spann puts it firmly:

... Die Sachsouveränität tritt an die Stelle der Volkssouveränität, Sachlichkeit an die Stelle subjektiver Willkür... 75

There is a strong emphasis on the organization aspect of the State, its capacity to act effectively. Neither Parliament, nor even civil servants provide the imaginative organizational drive of the State, but a spontaneously evolving circle of experts. ${ }^{76}$ While it is usual to speak of several elements of the State (territory, population and government) the essential element to stress is that of organization (organisierende Handlung). ${ }^{77}$ At the same time Spann considers the two aspects of his thought compatible. The State constitutes the self-organising dimension of community. It is embedded in relationships which he understands as organic. Hence it makes no sense to continue to talk of superior-subordinate, or master-slave relationships, given the common sense of community. ${ }^{78}$ Spann avoids any reification of the group/society etc. as an independent totality. The totality is an ever-evolving system or network of parts, in which the past as such has no merit. Rigidity, i.e. the attempt

72 Ibid., at 151: '... Hier geschieht keine Neugründung eines Staates durch Verträge Einzelner; sondern was hier vorgeht, ist die Umgliederung gegebener staatlicher Wirklichkeit, weil aus einem Staat ein Teil sich abzweigt...' This is Spann's way to describe the ending of the Russian and Austrian-Hungarian Empires after 1917-18.

73 Ibid., at 584.

74 Ibid., at 586-594.

75 Ibid., at 596 (author's translation): '... A Competence Sovereignty steps into the place of popular sovereignty, competence not subjective arbitrariness'.

76 Ibid., at 600 . The Staatstragende Stand comes from a Sachverständigenkreis, i.e. a circle of professionally competent people.

77 Ibid., at 606.

78 Ibid., at 607-613. 
to hold an evolving process at a particular point in time, is the antithesis of an organic perspective. ${ }^{79}$

Law, understood as an administrative expression of organizationalized social behaviour, is accorded the autonomy which it must have if it is to fulfil its clear role. At the same time, the confidence of the organic approach to social organization is that effective organization presupposes that one does not confuse law, economy and society. ${ }^{80}$ Once again it is not difficult to see how such a clear distinction between disciplines could make Spann as appealing as Kelsen to Verdross in his own intellectual development.

Spann supported the so-called Machtergreifung by the Nazis in Germany ( 30 January 1933) and made serious attempts to offer the Nazis academic and intellectual support in Berlin. He offered blueprints of a corporativist State. While he continued to be based in Austria the SS Leader Heydrich sought to recruit him. ${ }^{81}$ Nonetheless, a wide agreement exists that Spann was in no way a National Socialist or a fascist. His work is not ambiguous. It is his behaviour which might be characterized as naive and confused. The following critical reflections which have beeni maće abuut Spanin appear to appiy equaily weil to veraross.

It is precisely the romantic features of Spann's thought which mark his Weltfremdheit. The belief in a harmonious, objective, organic cultural identity of the German people was in fact a radical subjectivism which Spann had in common with the Nazis who equally tended to regard their own perspective as the only possible one, to be carried through at all cost: Subjectivity equals Objectivity. ${ }^{82}$ Schneller highlights how problematic the distinction is which both Spann and Verdross draw between the subjective and the objective. As we have seen with Verdross, objectivity is what distinguishes his German nationalism from individualist Western European nationalism. ${ }^{83}$ Yet the weakness remains that for Spann and Verdross the ideals or self-image which they hold are still the subjective impressions of a collective. These impressions are supposedly objective simply because they are collectively held. Nonetheless, what distinguishes Spann from National Socialism is, firstly, the complete absence of racism and the explicit disregard for so-called biological thought in his work. Secondly, Spann lacks any cult of violence,

Ibid., at 189-91.

80 O. Spann, Kategorienlehre, Gesamtausgabe, supra note 88, Vol. 6, taken from the 2nd edit. 1939, at $113-118,134$.

81 M. Schneller, Zwischen Romantik und Faschismus, Der Beitrag Othmar Spanns zum Konservatismus in der Weimarer Republik (1970), Ch. 6, at 143-164.

82 Schneller, supra note 81 , at 159 . The confused communality is summarized from an article written by a contemporary, Ilse Roloff (Schneller, at 159): 'Die gemeinsame Basis wird gewonnen, indem die voluntaristische Subjektivität der nationalsozialistischen Bewegung mit der wissenschaftlichen Objektivität der universalistischen Lehre verbunden wird. Danach heiBt Subjektivität der Wille, die eigene Auffassung als die einzig richtige durchzusetzen. Der subjektiv-kämpferische Einsatz aber geschieht für eine objektive Idee, für die schicksalhafte Mission des deutschen Volkes in der Welt - folglich ist Subjektivität gleich Objektivitäl...'

Verdross's self-presentation, Gauakt, supra note 9. 
harshness or power. ${ }^{84}$ It should be recalled that for Verdross organic theory was supposed to be the alternative to the power-politics (Machtdenken) of the Hegelian school with particular reference to the work of Somlo. A craving for power and violence has its root, in this organic perspective, in the alienation of individuals and peoples from one another, not in their supposedly too close association with one another. Communality of value minimizes, if it does not completely exclude, the necessity of struggle for power, or whatever.

The most serious weakness of Spann (and Verdross) lies not in his faith in the romantic magic of 'dialogic politics' 85 but in the reactionary quality of his (and Verdross's) political theology. The word reactionary simply means the belief that it is a sufficient response to the ills of today to put the clock back to a previous time when these ills were supposedly not present. As has been seen, Spann was aware of this possible criticism, saw himself as having a progressive concept of time and distinguished himself from those conservatives who, in his view, would attempt to make time stand still. ${ }^{86}$ Nonetheless, the criticism is made that the politicizing of religion makes of dogmatic Christianity an ethos of the State community. Such a functionalizing of religion forgets that Christianity treated the individual and not the community as eternal. Spann (and the so-called political Christians) constructed a metaphysical fiction of social order rooted in a religious idea. The medieval world was represented as anti-rational, while in fact the idealizing of the Middle Ages as a harmony of Stände which could avoid contractual arrangements was historically quite alien and an idealizing of collective egotism. This cult of medieval and then Christian Western culture was a deeply reactionary response to the radical individualization of modern industrial society which Spann hoped to sweep back with his call to integrative cultural nationalism. ${ }^{87}$

The reactionary quality of political Christianity was in fact central to the Austrian regime of 1934-38, similar to the authoritarian regimes in Portugal and Spain. The Vatican, the Episcopate and Clergy of Austria stood relatively firmly behind the regime. ${ }^{88}$ It wished to put the socio-economic clock back to an ideal medieval Stände society where each knew his place. The social basis of this political

84 Schneller, supra note 81, at 169-171. From 1936 attacks from the SS Schwarze Korps and Rosenberg concentrated on the lack of racial 'soundness' in Spann's thought and deplored his spirituality (Geistigkeit) as an intellectual Neuscholastik. On the materialism of biological reasoning, see Spann, Gesellschaftslehre, supra note 21, at 189-190. Verdross must have been aware of how Spann was regarded by the Nazis at this time if he was watching the Party's advance as acutely as Schönbauer claims.

85 After all this represents mainstream legal philosophy in Germany at present in the work of Jürgen Habermas and his sall for zwangsfreie Diskussion as the foundation for legal and political life, e.g. in Faktizität und Geltung (1992).

86 Gesellschafislehre, supra note 21, at 189-191. In Spann's view his own organic social theory implied a spirit of movement which was the very antithesis of the rigidity which he associated with a conservative perspective.

87 Schneller, supra note 81 , at 92-99.

88 Hanisch, 'Der Politische Katholizismus als ideologischer Träger des “Austrofaschismus"', in E. Talos and W. Neugebauer (eds), Austrofaschismus (4th ed., 1988) 53, at 58, 60. 
Catholicism was among farmers, small business people and particularly, the dominant civil service. ${ }^{89}$

This is very much Verdross's world. He draws upon Spann from the very outset to reactivate the cultural power of a 16th century Spanish catholic intellectual tradition which he sees threatened by modernist, Enlightenment individualism. $\mathrm{He}$ states explicitly the need to bridge the cultural void created from the 16th century to the appearance of thinkers such as Spann. The whole structure of the Verfassung is built around this theme from pages 12 to 42 . A criticism of 19th century positivism is followed by a return to a review of classical international law with Suarez and Grotius. The key argument after page 28 is about the renaissance of classical international law, after its having been shaken by positivism. However, the logical and hypothetical objectivity of Anzilotti and Kelsen had to be more firmly grounded in objective values of the Cosmos (at page 31). This is found in Spann's social theory which allows for a reworking of Spanish thinkers such as Vitoria (at pages 38 to 42 ).

Verdross's academic work can be seen in the context of his own complex involvement in the Austrian politics of the 1930s. One very full account of his activity at this time is offered by Ernst Schönbauer, the Dean of the Vienna Law Faculty during Verdross's suspension. He states that from early 1934 Verdross sympathized openly with National Socialism. In Schönbauer's view Verdross was open in his opposition to the Schuschnigg regime and treated it as doomed from about 1936. Verdross was enthusiastic about the Anschluss. ${ }^{90}$ This is what one would expect from Verdross's call for unification in 1919. His letter to Schuschnigg is dismissed by Schönbauer as not detracting from his sympathy with unification. This is, of course, a vital part of the argument to have Verdross reinstated as a professor. Thus, two members of Austrian political Catholicism identified with the right wing deutsch-national action, Arthür Seyss-Inquart and Karl Gottfried Hugelmann, ${ }^{91}$ are closely associated with Verdross. ${ }^{92}$ In other words, Verdross was perfectly willing to stand up openly and be counted for political persons who were in difficulty, even to the point of visiting one of them in prison.

Ibid., at 66: '... unter der Beamtendominanz - besonders stark ausgebildet, hielten sich ständische Verhaltensmuster besonders lange...'

90 Report of Emst Schönbauer to Reichskommissar für die Wiedervereinigung, Vienna 14 February 1939 given by Prof. E. Rabofsky to Univ. Doz. Dr. Oliver Rathkolb with the note, 'Die Kopien Eibl und Schönbauer sind von Abschriften hergestellt worden, die ich 1945 anfertigen lieB. Die Originale müssen sich bei der Stapo (Staatspolizei, Anm.) befinden, für die Transkripte des Inhaltes verbürge ich mich. E. Rabofsky'. Schönbauer's aim, as Dean, is to keep in the Faculty a colleague whom he regards as an outstanding teacher and scholar. His view of the suspension was that it was part of an intrigue by much less qualified Nazis to take Verdross's position.

91 See also Hanisch, supra note 88, at 55 .

92 Schönbauer, supra note 90 . That is to say Verdross was impressed by the former as national und katholisch and yet able to win Hitler's confidence, so this belief led him to speculate in his letter to Schuschnigg about a reconciliation with the possibility of a ministry for himself. Schönbauer praises Verdross's courage for visiting Hugelmann in prison when he was arrested after 25 July 1934 , speaking out very openly for him. 
Schönbauer accuses Verdross of opportunism, of moving all the way from neoKantian support of Kelsen in the early 1920 s to a marked conservative nationalism in the mid-1930s. ${ }^{93}$ However, it remains difficult to decide about charges of opportunism when they come from those committed to a fanatical movement and are faced with others willing to cooperate up to a point but definitely in possession of their own agenda. For instance, on one occasion Schönbauer notes how Verdross shared a common political platform with DollfuB, but avoided any political comment. Schönbauer remarks that Verdross spoke only of the Christian community of nations in Europe. ${ }^{94}$ For Verdross, the Christian Europe of Nations included the Germans as a single nation. The Nazi authorities accepted Schönbauer's arguments, but reinstated Verdross without allowing him to continue teaching his Christianbased philosophy of law. 95 .

How remote the world of Spann and Verdross was from the ethos of the survival of the fittest (social Darwinism) of National Socialism is stressed by numerous authors such as Hanisch, Schneller and Johnston. Hanisch highlights with respect to Austrian political Catholicism in the 1930s a longing for social harmony and freedom from conflict. This led to a desire to replace a social Darwinist struggle for life with a supposedly natural, harmonious society. As Hanisch puts it:

Organische, naturrechtliche Gesellschaft heiBt: daB die sozialen Hierarchien geachtet werden...96

The movement expressed not a pure ideological manipulation but deep-lying dreams and longings (Träume und Sehnsüchte), marking an inability to tackle conflict and a craving for harmony to escape the social tensions of an increasingly fragmented society. ${ }^{97}$ In other words, despite the effective crushing of an autonomous labour movement, and an intense anxiety in the face of Bolshevism, this movement of political thought and activity retained a quality of Schönheitsdenken which made it an unequal partner for National Socialism. ${ }^{98}$

94 Ibid. '... Zwar trat er noch 1933 als Redner zusammen mit DollfuB bei dem groBen Katholikentage auf, aber er vermied dabei jede politische ÄuBerung und sprach nur über die christliche Völkergemeinschaft Europas...' This is also part of Schönbauer's strategy to distance Verdross from the Austrian regime.

95 Schönbauer was a scholar in his own right. Although a convinced NS party member he did not, as a Roman law scholar. simply take the party line that Roman law encouraged only individualism and had no communitarian dimension, see Stolleis, "Fortschritte der Rechtsgeschichte" in der Zeit des Nationalsozialismus?', in M. Stolleis, Recht im Unrecht, Studien zur Rechtsgeschichte des Nationalsozialismus (1994) 77 et seq.

96 Hanisch, in Talos et al., supra note 88, at 67: '... organic-natural law society means that the social hierarchies are observed' (translation by the author).

97 Tbid.

98 For a similar assessment of Spann, see W.J. Johnston, Dsterreichische Kultur- und Geistesgeschichte. Gesellschafi und Ideen im Donauraum 1848-1938 (3rd ed., 1992) 313-317. Johnston rejects Karl Polanyi's charge of fascism against Spann, made in the 1930s, that Spann had constructed a totalitarian society which would sacrifice the individual. Johnston's criticism is nonetheless severe that thinkers such as Spann took the study of intellectual history as a substitute 
One final criticism which was made of Spann should also apply to Verdross. Spann took the study of the history of ideas as a substitute for a political reality which it served to hide. ${ }^{99}$ Without a full analysis of the 1937 textbook it is difficult to make the same criticism of Verdross. However, it has already been noted, with respect to the Verfassung, that Verdross does not carry through the implications of his Spann-based theory systematically for the whole of his text. It requires at least as much historical and historiographical research as has been undertaken here to track down what Verdross could have understood the significance of Spann to be. In this sense there is not a direct interaction in his work between his theoretical and his practical interests. For instance, he uses Spann as a more effective tool to refute legal positivism than either Kelsen or Suarez. It is possible that the relative decline of interest in theory in more pragmatic post-1945 times is attributable to this tendency of pre-war theory to obscure erudition - which it has been one of the aims of this article to unravel.

\section{Postscript on Post-war Germany and Organic Legal Theory}

Organic thinking does not have a good name in post-war Germany. It is taken to be one of the cardinal marks of Organologie that it seeks innumerable metaphors of the State as family as plant, as totality and as person, to harken back to more perfect, harmonious pre-modern times. It is thoroughly discredited in a now dominant modernist German political and legal thinking. Modernist refers to the present-day overwhelming West German acceptance of the virtues of the 17th and 18th century political and social Enlightenment in England and France. Habermas and Luhmann are taken to be the leading German social theorists who so understand themselves. Both have made comprehensive statements on legal theory. However, the question might be asked whether there are traces of Organologie in the thought of Luhmann. Nonetheless, it can be said that at present there is no place for organic thinking in mainstream German public law theory. This has been characterized as one of the dilemmas of German conservatism. ${ }^{100}$

for political reality and accepted no responsibility for the interpretations which might be put on their work. In fact, however, the unfortunate Spann's only achievement - the Nazis never reinstated him and he failed after 1945 to be reinstated -, was in Johnston's words '... daB er eine so gut wie verlorene Tradition wieder zustande brachte...' Johnston, supra note 98, at 316.

100 M. Greiffenhagen, Das Dilemma des Konservatismus in Deutschland (1986) Chapter 10 Organologie, 200-218, esp. at 202-203 for legal literature, and at 216-216 for the concept of Totalität and the work of Othmar Spann. It will be interesting to explore whether there are, nonetheless, organic traces in the legal-social theory of $\mathrm{N}$. Luhmann. His latest legal work Das Recht der Gesellschaft (1993) differs very little in style from Spann's Gesellschaftslehre except for his conviction that there is no centre holding social groups together. His legal theory is, in terms of the relation of law to other disciplines, merely a repetition of that developed by Spann and taken up by Verdross. Law is a completely autonomous meaning-world of its own which relates to the nonlegal entirely in terms of accepting and rejecting the outside - the non-law - within its own 
At the same time brief mention might be made of the following points.. It is of interest that the two thinkers considered here both opposed a model of the nationState as being essentially autonomous in its relations with other nation-States. The States of Europe (Christian and Western Europe) had to be integrally united in a wider (international) community. Unity (Einheit) is the key word for Verdross. Totality (das Ganze) was the key word for Spann. Secondly, both retained the romantic ideal that political life was a conversation. As Spann puts it

... Du hast Neues in mir geschaffen wie die Worte der Sprache erst durch die Mitbedeutungen der anderen Worte einen Sinn erhalten... 01

Finally, more clearly for Spann than for Verdross, politics should remain in the hands of the 'competent' (die Sachsouveränität tritt an die Stelle der Volkssouveränität). It is a commonplace of German public debate that Sachkompetenz has, mercifully, replaced the grand ideological debates (for instance between Kelsen and Schmitt) of the inter-war period. These three elements in the thought and concerns of Othmar Spann and Alfred Verdross are still very prominent indeed in contemporary German political and legal culture.

meaning-structures. Both Spann and Luhmann come up with the irritating definition 'Law is Law', meaning it is not something else!

101 Gesellschaftslehre, supra note 21, at 144 (author's translation): '... You have created something new in me just as the words of a language take on new meaning through being related to one another...' 